ies Bibliographer, Harold B. Lee Library, Brigham Young University, Provo, UT 84602; Thomas D. Kilton, Assistant Modern Languages and Linguistics Librarian, University of Illinois, Urbana, IL 61801 .

Member-at-Large: Helga Borck, Assistant for
Resources, Collection Management \& Development Division, New York Public Library, New York, NY 10018; Barbara L. Walden, History Bibliographer, University of Minnesota Libraries, Minneapolis, MN 55455.

\title{
Managing a library publications program
}

\author{
By Jon Eldredge \\ Chief of Collections and Information Resources \\ University of New Mexico Medical Center Library
}

\section{The University of California, Irvine, wins the John Cotton Dana Award for its unique approach.}

$\mathbf{T}$ on a Special Award in the 1985 John Cotton Dana Library Public Relations Award contest for its unique and effective administration of a library publications program. The UC Library was one of 15 winners selected from the 173 entrants that participated in this year's contest. This annual contest has recognized the achievements of outstanding library public relations programs since its inception in 1946. Three university libraries and one community college library participated in the contest this year.

The UC Irvine Library provided clear evidence that it has been managing a superb publications program. This award-winning publications program has produced an exemplary assortment of brochures, guides, maps, bibliographies, and newsletters which all share a coordinated graphic arts format. A standard masthead scheme integrated into all items produced in this program, plus a combination of complementary colors have con- tributed to the pleasant visual effect produced by these publications. This unified design has been enhanced by the placement of these publications on handsome display racks located at service areas throughout the library system.

The most remarkable aspect of this program actually pertains to its method of administration. This large-scale publications program, capable of producing numerous printed items each year, has been managed by a small committee of professional librarians who work within the UC Irvine library. This committee has relied greatly upon the widespread participation and high level of cooperation of librarians within the Library to make this program a success. In the opinion of this judge the publications themselves must possess such a high degree of quality that the UC Irvine library entry would have won an award on the basis of this accomplishment alone. The program has acquired additional distinction though, on the merits of its unique method of administering with a committee. 


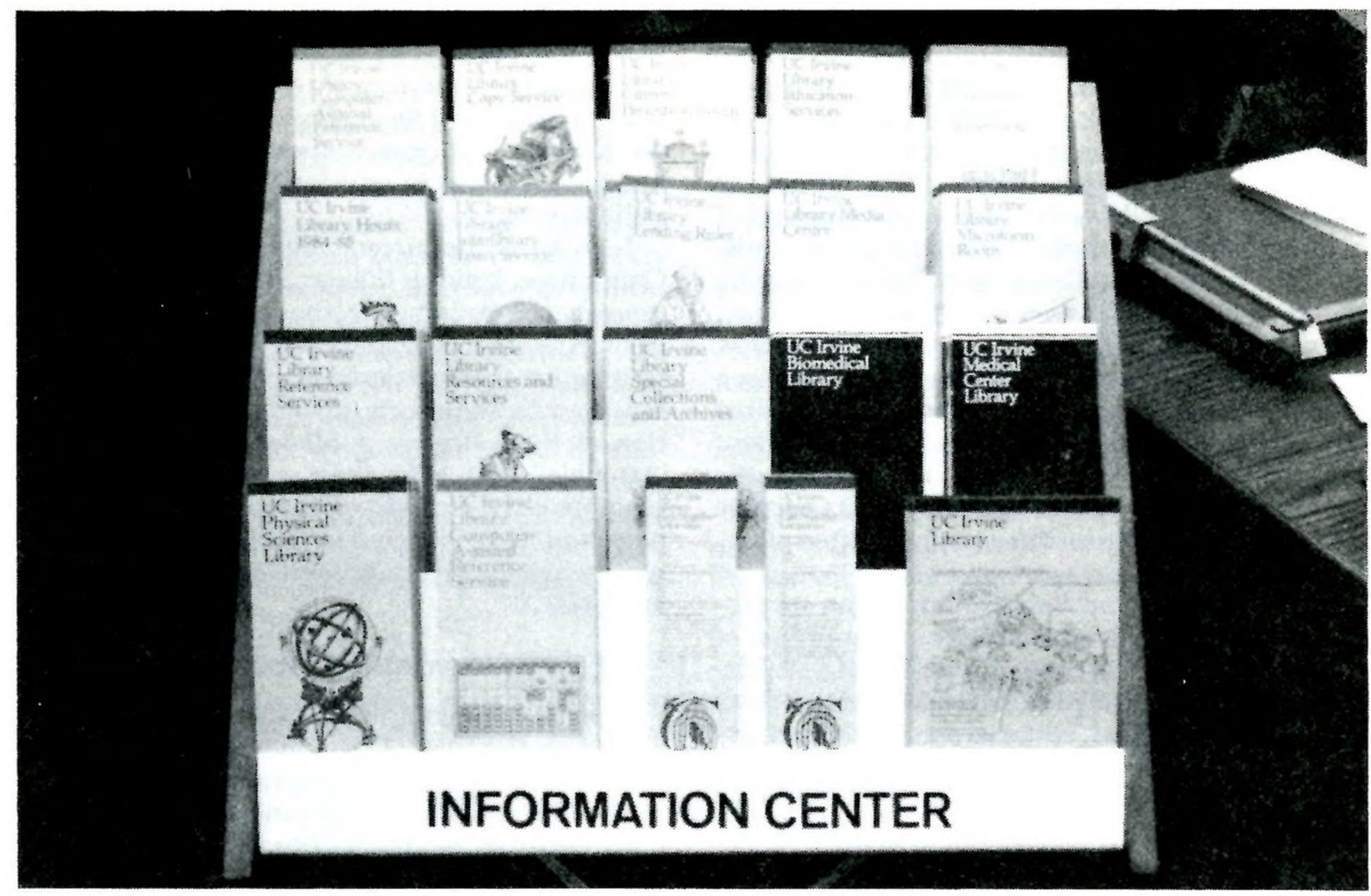

UC Irvine's library brochure display.

This unusual approach to the planning and production of high-quality publications has proven to be a very effective means of administration. The success of this program runs counter to conventional wisdom surrounding the management of a major public relations program. ${ }^{1}$

Since its initial phase, this program has expanded from a total number of 17 types of publications to its present size of 60 separate publication titles. These varied publications promote major service areas, branches, and collections located in the UC Irvine library. Uses for these publications range from campus orientation activities by the Dean of Students Office to the conducting of library instruction sessions in the classroom. The program publishes 33 different reference guides, 16 department brochures, numerous special collection descriptions, separate newsletters for internal and external audiences, and a faculty awareness bulletin. The texts of the publications contain only the most essential information about any particular topic. This economy of language used in these publications contributes to their simple, uncluttered appearance.

Although all UC Irvine library publications

\footnotetext{
${ }^{\text {I }}$ The author knows of only three academic libraries which utilize the committee approach to public relations. Normally, an individual located at a fairly high level in the library administrative structure assumes responsibility for public relations.
}

have an easily recognized, standard masthead, various publication series feature their own distinctive thematic elements and formats. These distinct characteristics aid the user in identifying particular types of publications. For example, Biomedical Library and Medical Center Library publications display a logo which identifies them as being relevant to those branches in the UC Irvine library. These branch library publications also are printed on a slightly different, metallic-shaded paper so they can be more easily identified by interested users.

The Main Library's reference guides feature a standard format that sets them apart from other publications as well. The series of publications describing the service areas of the Main Library display a variety of quaint, slightly archaic styled pieces of artwork on their different covers. The Interlibrary Loan Services' brochure portrays an early-era hot air balloon, the Copy Service brochure shows an old printing press, and the Media Center presents an old print of a gramophone. Through the use of common and distinctive elements integrated into a compatible color scheme these publications visually represent the unity and diversity of resources found in the UC Irvine library system.

The present Publications Committee and its impressive series of library publications developed from a modest origin. Several years ago, the library's Public Services Committee conducted a needs assessment survey of all professional librari- 
ans in the UC Irvine library. Survey respondents cited the need for improved publications as a highpriority library project. To fill this need, the Public Services Committee organized a Task Force on Publications. This Task Force eventually became a permanent Publications Committee. The Task Force carefully followed a clearly articulated set of goals and objectives derived from the library's mission and basic goals. One contest judge reviewing the entry described its program goals and objectives statement as a "model document." The statement explicitly defines and distinguishes between goals and objectives to avoid the common pitfall of confusing these two elements of a Public Relations program. Documentation for this entry reveals that the Task Force never strayed from its purpose by closely adhering to this lucidly written statement.

The Task Force on Publications began its program by performing an inventory and appraisal of the library's then existing 17 publications. The Task Force instituted guidelines concerning a common thematic format, editorial standards, and levels of acceptable quality for materials used for graphic artwork to be included in all new library publications. The library's administration extended its support to the Task Force in this instance, as on numerous other occasions, by granting it final editorial authority on the publications. The Campus Publications Office frequently contributed its expert assistance to the Task Force on many instances as well. The Task Force attained its goals and objectives by efficiently harnessing available on-campus resources rather than by soliciting special funding elsewhere from sources such as foundations or the state legislature. The Task Force instituted further efficiency to the process of publishing these items by reorganizing existing practices and procedures. Most of these management guidelines have remained in effect to the present.

Task Force members revised existing publications, or initiated the production of new ones, by seeking the assistance of librarians who were significantly involved with the featured resource or service. These librarians drafted the texts of these publications. The Task Force reasoned that these librarians were the most qualified individuals to describe the specific service or resource for prospective users. Although the Task Force potentially wielded final editorial authority on the content of these texts, its members found they typically had only to coordinate and advise these librarians' work. The Task Force mainly concerned itself with design, typesetting, and format matters related to these publications.

Practical experience soon taught Task Force members to supervise personally the actual production process at the print shop to ensure that desired results of the items would be obtained. Experience also convinced Task Force members that this group operated optimally with only three members. This small size allowed for maximum flexibil- ity, accountability and efficiency for the group. When the Task Force later became a permanent Publications Committee it retained this particular feature. In spite of its small size, the Task Force always worked in close cooperation with other librarians engaged in composing the texts of these publications.

Joan Ariel, the current chair of the Publications Committee, believes the success of this unique program can be explained by the nature of the activity itself. Ariel reports that unlike the abstract sense of satisfaction that one derives from public services librarianship, the efforts expended toward the creation of these library publications has yielded a "tangible" product for those persons involved. This tangible characteristic of the program has filled Ariel and her colleagues in the UC Irvine Library with what she terms "a sense of accomplishment and pride."

\section{A winning formula}

The UC Irvine Library won a JCD Special Award on the basis of the innovativeness and success of its publications program. ${ }^{2}$ The program earned the praise of contest judges for its conscientious effort to relate the library's mission to its goals, objectives, and activities. The program had clearly defined target audiences (that is, not just "everybody") with which it sought to establish and maintain communication. The judges were impressed with the UC Irvine Library's wise utilization of available resources rather than by any large amounts of money expended on the publications program.

The contest judges also favorably noted the evaluation documentation provided by the entry scrapbook. Whenever possible, the entrants presented measurable indicators of the program's success. For instance, the UC Irvine Library's evaluation methods carefully avoided commonplace reliance upon vague, anecdotal indicators of supposed success characterized with statements like, "lots of favorable comments." The entrants instead presented more dependable forms of evaluation such as statistics on the distribution, circulation cycles, and forms of usage for their publications. The UC Irvine Library scrapbook also supplied qualitative forms of evaluation. In this regard, the scrapbook provides samples of the original printed items and contrasts them with the new, vastly improved series of publications.

The scrapbook entry submitted by the UC Irvine Library has a number of laudable features which help explain why it won an award. First, it has a logical organization to its various sections. Second,

\footnotetext{
${ }^{2}$ Readers interested in learning more about the history of academic library involvement in the contest or in obtaining advice on how to enter should consult the June 1983 and July/August 1984 issues of $C \triangleleft R L$ News, or the Summer 1985 issue of Special Libraries.
} 
it offers the reader a very clear idea of how the publications program has been administered and evaluated. The reader does not have to decipher the scrapbook merely to understand what the program has accomplished. The scrapbook still provides judges with all pertinent information. Most importantly, the scrapbook is concise. A judge can read it entirely in less than fifteen minutes. It must be remembered that contest judges have only five working days to evaluate numerous submissions. Therefore, concise and easily-understood entries have a far greater chance of success in winning an award.

Prospective entrants may benefit from reviewing the scrapbook or audio-visual entries of winners from past contests. These entries are available via interlibrary loan from the ALA Headquarters Library. Winners in recent years have indicated that the opportunity to examine personally these examples of winning entries aided them in preparing their own contest submissions. Entries that contain appropriate forms of documentation to support claims of having had a successful PR program fare better in the judging process. The judges this year were impressed by an entry from the National Geographic Society Library, for example, which contained unit-cost and distribution statistics. In addition, entries that include library use statistics from more than a one or two-year period normally receive high marks in the judging process. This information helps judges to assess whether a rise in use statistics can be attributed to the PR program, rather than merely signifying an irregularity in user activity.

The contest co-sponsor, the H.W. Wilson Company, provides interested libraries with a free information packet about the John Cotton Dana Li-

TABLE 1: General Data

\begin{tabular}{cccc}
\hline \hline $\begin{array}{c}\text { Judging } \\
\text { Year }\end{array}$ & $\begin{array}{c}\text { Total Number } \\
\text { of Entrants }\end{array}$ & $\begin{array}{c}\text { Number of Academic } \\
\text { Library Entrants }\end{array}$ & $\begin{array}{c}\text { Academic Libraries } \\
\text { as a Percentage of } \\
\text { Total Number } \\
\text { of Entrants }\end{array}$ \\
\hline 1980 & 174 & 10 & $5.7 \%$ \\
1981 & 166 & N/A & N/A \\
1982 & 145 & 5 & $3.4 \%$ \\
1983 & 155 & 4 & $2.6 \%$ \\
1984 & 144 & 9 & $6.3 \%$ \\
1985 & 173 & 4 & $2.3 \%$ \\
\hline
\end{tabular}

TABLE 2: Performance of All Library Category Entrants

\begin{tabular}{cccc}
\hline \hline $\begin{array}{c}\text { Judging } \\
\text { Year }\end{array}$ & $\begin{array}{c}\text { Number of } \\
\text { JCD Awards }\end{array}$ & $\begin{array}{c}\text { Number of } \\
\text { Special Awards }\end{array}$ & $\begin{array}{c}\text { Rate of Success: } \\
\text { Total Number of Awards } \\
\text { as Percentage of Entries }\end{array}$ \\
\hline 1980 & 3 & 20 & $13 \%$ \\
1981 & 4 & 21 & $15 \%$ \\
1982 & 4 & 15 & $13 \%$ \\
1983 & 7 & 16 & $15 \%$ \\
1984 & 6 & 16 & $15 \%$ \\
1985 & 1 & 15 & $9 \%$ \\
\hline
\end{tabular}

TABLE 3: Academic Library Performance

\begin{tabular}{lccc}
\hline $\begin{array}{c}\text { Judging } \\
\text { Year }\end{array}$ & $\begin{array}{c}\text { Number of } \\
\text { JCD Awards }\end{array}$ & $\begin{array}{c}\text { Number of } \\
\text { Special Awards }\end{array}$ & $\begin{array}{c}\text { Rate of Success: } \\
\text { Awards as a Percentage } \\
\text { of Entries }\end{array}$ \\
\hline 1980 & 0 & 0 & 0 \\
1981 & 0 & 0 & 0 \\
1982 & 0 & 1 & $20 \%$ \\
1983 & 1 & 0 & $25 \%$ \\
$1984^{*}$ & 0 & 2 & $22 \%$ \\
1985 & 0 & 1 & $25 \%$ \\
\hline
\end{tabular}

*Does not include an academic library that entered and won an award in the Special Library Category. 
brary PR Award. Prospective entrants should know that contest winners this year such as the UC Irvine Library and the National Geographic Society Library mentioned that they found this packet to be most useful in preparing their entries. The contest guidelines and rules described in this packet are intended to steer entrants toward winning an award.

An ideal public relations program includes the essential elements of healthy staff relations, a commitment to serving the public, marketing, publicity and creativity. Yet, successful public relations is involved even more in the somewhat intangible realm of having a genuinely positive attitude toward the public and in the domain of having an innovative concept of management. All libraries literally have some sort of "relations" with the public. Public relations in the context of this discussion though, means having a deliberate, systematic and planned approach to maintaining or improving the relationship between the library and specifically identified groups.

The UC Irvine Library serves as a noteworthy example of how well academic libraries can do in this contest with the creative management of a seemingly commonplace library activity like publishing brochures, guides and newsletters. Only a small number of the estimated 5,443 academic libraries in the U.S. and Canada have entered the contest since $1980 .{ }^{3}$ As the accompanying tables indicate, however, academic libraries entering the contest perform far better than the typical contest entry in other categories. Although the contest employs no quota systems for different categories of entrants, academic libraries experience an aboveaverage chance of winning awards in this PR award contest.

${ }^{3}$ American Library Association, Library Administration and Management Association. A Market Overview of the John Cotton Dana Library Public Relations Award Contest. Unpublished, internal document. Chicago: ALA, 1984.

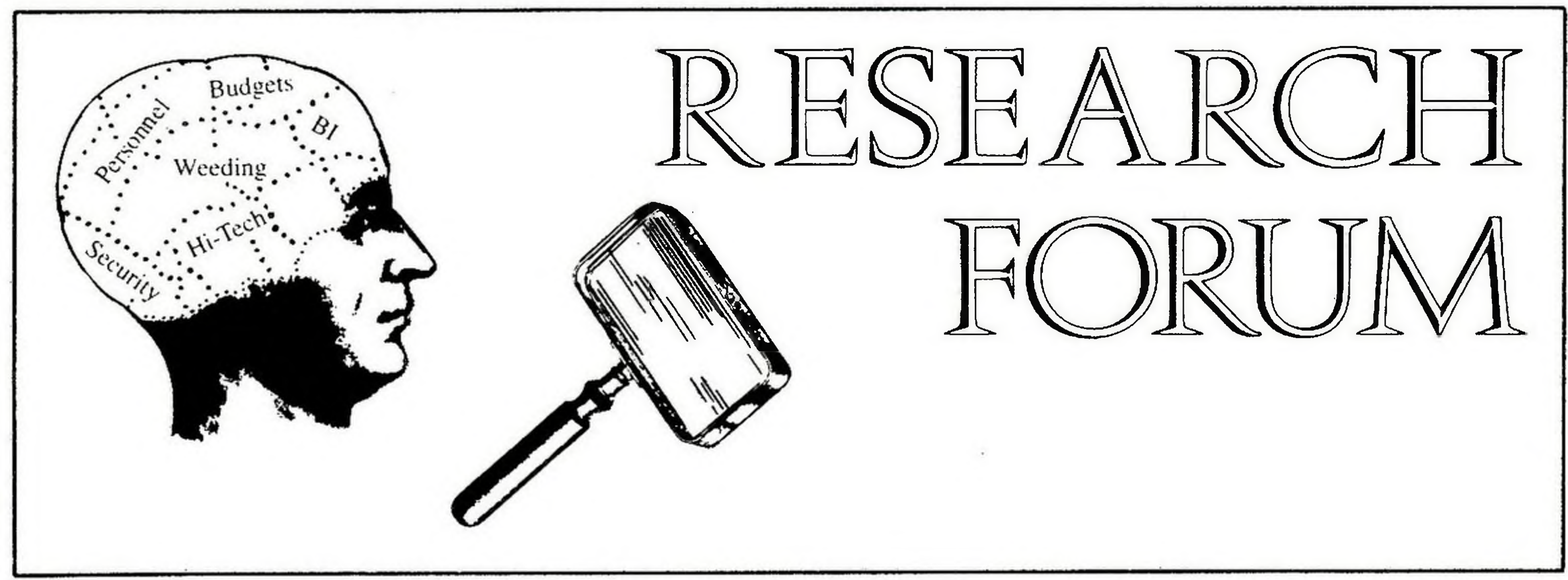

\section{Overlapping viewpoints}

\author{
By Paul Mosher \\ Deputy Director of Libraries \\ Stanford University
}

The point that Jeffry Larson makes about the desirability of overlap among smaller instructional collections is well taken (C $b R L$ News, October 1985, pp.486-87). It seems obvious to me that the smaller the collection the greater the probability, and even the desirability, of overlap-particularly in instructional components-of the collection.

But my point was not that smaller libraries should reduce the levels of duplication in their instructional collections. I would argue quite the reverse. My point was to emphasize the benefits of collaboration and resource sharing among libraries in the support of their research, not their curricu- lar, efforts. We all realize that the research components of our universities require us to develop research collections of lesser or little used materials in many fields. These materials may not need to be duplicated as heavily if we are better aware both of the patterns of acquisition and the strengths of existing holdings of other libraries in some of these areas where we are pressed continually to expand our research holdings.

It behooves large libraries to examine this issue carefully and determine the degree to which overlap in collecting may be desirable, and hopefully to arrange patterns of collecting which tend to take advantage of the strength of other libraries' collections.

So I think Larson has misconstrued my point, without it in any way damaging the substance of the points he makes about instructional collections in smaller libraries. His conclusion that the finding of less-than-expected overlap among instructional collections should give collection developers pause about what direction they should pursue in strengthening these libraries is an excellent one and should be made. 